\title{
Front Matter: Volume 9869
}

, "Front Matter: Volume 9869," Proc. SPIE 9869, Mobile Multimedia/Image Processing, Security, and Applications 2016, 986901 (28 September 2016); doi: $10.1117 / 12.2244115$

SPIE Event: SPIE Commercial + Scientific Sensing and Imaging, 2016, Baltimore, MD, United States 


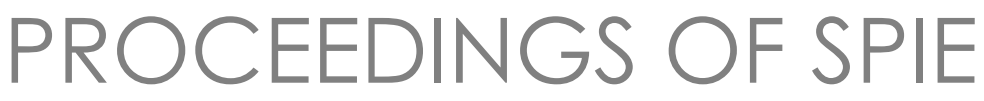

\section{Mobile Multimedia/Image Processing, Security, and Applications 2016}

Sos S. Agaian

Sabah A. Jassim

Editors

18-19 April 2016

Baltimore, Maryland, United States

Sponsored and Published by

SPIE 
The papers in this volume were part of the technical conference cited on the cover and title page. Papers were selected and subject to review by the editors and conference program committee. Some conference presentations may not be available for publication. Additional papers and presentation recordings may be available online in the SPIE Digital Library at SPIEDigitallibrary.org.

The papers reflect the work and thoughts of the authors and are published herein as submitted. The publisher is not responsible for the validity of the information or for any outcomes resulting from reliance thereon.

Please use the following format to cite material from these proceedings:

Author(s), "Title of Paper," in Mobile Multimedia/lmage Processing, Security, and Applications 2016, edited by Sos S. Agaian, Sabah A. Jassim, Proceedings of SPIE Vol. 9869 (SPIE, Bellingham, WA, 2016) Six-digit Article CID Number.

ISSN: 0277-786X

ISSN: 1996-756X (electronic)

ISBN: 9781510601109

Published by

SPIE

P.O. Box 10, Bellingham, Washington 98227-0010 USA

Telephone +1 3606763290 (Pacific Time) · Fax +1 3606471445

SPIE.org

Copyright (c) 2016, Society of Photo-Optical Instrumentation Engineers.

Copying of material in this book for internal or personal use, or for the internal or personal use of specific clients, beyond the fair use provisions granted by the U.S. Copyright Law is authorized by SPIE subject to payment of copying fees. The Transactional Reporting Service base fee for this volume is $\$ 18.00$ per article (or portion thereof), which should be paid directly to the Copyright Clearance Center (CCC), 222 Rosewood Drive, Danvers, MA 01923. Payment may also be made electronically through CCC Online at copyright.com. Other copying for republication, resale, advertising or promotion, or any form of systematic or multiple reproduction of any material in this book is prohibited except with permission in writing from the publisher. The CCC fee code is 0277-786X/16/\$18.00.

Printed in the United States of America.

Publication of record for individual papers is online in the SPIE Digital Library.

\section{SPIE. DIGITAL}

Paper Numbering: Proceedings of SPIE follow an e-First publication model. A unique citation identifier (CID) number is assigned to each article at the time of publication. Utilization of CIDs allows articles to be fully citable as soon as they are published online, and connects the same identifier to all online and print versions of the publication. SPIE uses a six-digit CID article numbering system structured as follows:

- The first four digits correspond to the SPIE volume number.

- The last two digits indicate publication order within the volume using a Base 36 numbering system employing both numerals and letters. These two-number sets start with 00, 01, 02, 03, 04, $05,06,07,08,09,0 A, 0 B \ldots$ OZ, followed by 10-1Z, 20-2Z, etc. The CID Number appears on each page of the manuscript. 


\title{
Contents
}

\author{
$\checkmark$ Authors \\ vii Conference Committee
}

\section{SESSION 1 MULTIMEDIA ALGORITHMS AND SYSTEMS}

986902 Simultenious binary hash and features learning for image retrieval [9869-1]

986903 Facial expression identification using 3D geometric features from Microsoft Kinect device [9869-2]

986904 A new color transfer quality measure [9869-3]

986905 Missing data reconstruction using Gaussian mixture models for fingerprint images [9869-4]

986907 Wavelet domain Retinex algorithm for image contrast enhancement [9869-6]

\section{SESSION $2 \quad$ IMAGE PROCESSING AND ENHANCEMENT}

986908 Video stabilization using space-time video completion [9869-7]

986909 Improved deadzone modeling for bivariate wavelet shrinkage-based image denoising [9869-8]

9869 OA Fruit bruise detection based on 3D meshes and machine learning technologies [9869-9]

9869 OB Automatic segmentation and measurements of gestational sac using static B-mode ultrasound images [9869-10]

9869 OC Automatic layer segmentation of H\&E microscopic images of mice skin [9869-11]

9869 OD Automatic detection of the hippocampal region associated with Alzheimer's disease from microscopic images of mice brain [9869-12]

9869 OE Image denoising using a combined criterion [9869-13]

\section{SESSION 3 MULTIMEDIA SECURITY AND SENSING}

9869 OF Consideration of techniques to mitigate the unauthorized 3D printing production of keys [9869-14]

9869 ol Single authentication: exposing weighted splining artifacts [9869-17] 
9869 0J 3D change detection in staggered voxels model for robotic sensing and navigation [9869-18]

9869 OK A hybrid algorithm for the segmentation of books in libraries [9869-19]

$9869 \mathrm{OL}$ Wireless imaging sensor network design and performance analysis [9869-20]

INTERACTIVE POSTER SESSION

$9869 \mathrm{ON} 2 \mathrm{D}$ hexagonal quaternion Fourier transform in color image processing [9869-21]

$98690 \mathrm{OQ}$ Contour detection based on wavelet differentiation [9869-24]

9869 OR Automatic image cracks detection and removal on mobile devices [9869-25]

9869 OS Method for modeling post-mortem biometric 3D fingerprints [9869-26]

9869 ОT Automated classification of histopathology images of prostate cancer using a Bag-ofWords approach [9869-27]

9869 OU Alpha trimmed correlation for touchless finger image mosaicing [9869-28]

9869 OV Histogram of oriented phase (HOP): a new descriptor based on phase congruency [9869-29] 


\section{Authors}

Numbers in the index correspond to the last two digits of the six-digit citation identifier (CID) article numbering system used in Proceedings of SPIE. The first four digits reflect the volume number. Base 36 numbering is employed for the last two digits and indicates the order of articles within the volume. Numbers start with 00, 01, 02, 03, 04, 05, 06, 07, 08, 09, OA, OB...0Z, followed by 10-12, 20-2Z, etc.

Agaian, Sos S., 02, 04, 05, 08, ON, OS, OT, OU

Al-Assam, Hisham, OB, OC, OD

Albaidhani, Tahseen, OD

Al Jawad, Naseer, 03

Al-karawi, Dhurgham, OB

Asari, Vijayan K., OJ, OV

Bao, Long, 04

Bezuglov, D., OQ

Bourne, Tom, OB

Ciptasari, Rimba W., Ol

DelMarco, Stephen, 09

Du, Hongbo, 03, OB

Dubovskov, Vadim, OE

Egiazarian, K. O., 02

Farren, Jessica, OB

Frantc, V. A., 02, 08

Gapon, N., 08, OR

Grigoryan, Artyom M., ON

Hampshire, Brandon, 0J

Han, Dongxu, 03

Hawkes, Cheryl, OD

$\mathrm{Hu}$, Zilong, OA, OK

Hussein, Saif, OC

Ibrahim, Dheyaa Ahmed, OB

Jassim, Sabah, OB, OC, OD

Kamath K.M., Shreyas, OS

Kerlin, Scott, OF

Kuzin, A., OQ

Lei, Liang, OK

Liu, Ruixu, 0J

Makov, S. V., 02

Marchuk, Vladimir, 02, 08, OE, OR

Maslennikov, Stansilav, OE

Mulawka, Marzena Mary Ann, 05, OU

Onoyko, Tatyana, OE

Panetta, Karen, 04

Pismenskova, M., OR

Ragb, Hussin K., OV

Rajeev, Srijith, OS

Rajendran, Rahul, OU

Rao, Shishir P., 05, OU

Reinecke, Gary, 05

Sanghavi, Foram M., OT

Selway, Joanne, OC

Semenishchev, Evgeny, 02, 0E

Shrafel, Igor, OE

Shrayfel, I., 08

Sizyakin, R., OR

Straub, Jeremy, OF
Sundaram, Ramakrishnan, OL

Tang, Jinshan, OA, OK

Tokareva, S., OR

Troy, Mike, 05

Unaldi, Numan, 07

Voronin, V. V., 02, 08, 0Q, OR

Yeole, Rushikesh D., 05

Zhang, Ping, OA 
Proc. of SPIE Vol. $9869986901-6$

Downloaded From: https://www.spiedigitallibrary.org/conference-proceedings-of-spie on 26 Apr 2023 Terms of Use: https://www.spiedigitallibrary.org/terms-of-use 


\section{Conference Committee}

Symposium Chair

Ming C. Wu, University of California, Berkeley (United States)

Symposium Co-chair

Majid Rabbani, Eastman Kodak Company (United States)

Conference Chairs

Sos S. Agaian, The University of Texas at San Antonio (United States)

Sabah A. Jassim, The University of Buckingham (United Kingdom)

Conference Co-chairs

Eliza Yingzi Du, Qualcomm Inc. (United States)

Stephen P. DelMarco, BAE Systems (United States)

Conference Program Committee

David Akopian, The University of Texas at San Antonio (United States)

Vijayan K. Asari, University of Dayton (United States)

Cesar Bandera, BanDeMar Networks (United States)

Chang Wen Chen, University at Buffalo (United States)

Reiner Creutzburg, Fachhochschule Brandenburg (Germany)

Frederic Dufaux, Telecom ParisTech (France)

Touradj Ebrahimi, Ecole Polytechnique Fédérale de Lausanne

(Switzerland)

Erlan H. Feria, College of Staten Island (United States)

Artyom M. Grigoryan, The University of Texas at San Antonio (United States)

Phalguni Gupta, Indian Institute of Technology Kanpur (India)

Yo-Ping Huang, National Taipei University of Technology (Taiwan)

Jacques Koreman, Norwegian University of Science and Technology

(Norway)

Maryline Maknavicius, TELECOM \& Management SudParis (France)

Alessandro Neri, Universitá degli Studi di Roma Tre (Italy)

Cheryl L. Resch, Johns Hopkins University Applied Physics Laboratory

(United States)

Haleh Safavi, NASA Goddard Space Flight Center (United States)

Harin Sellahewa, The University of Buckingham (United Kingdom) 
Yuri Shukuryan, National Academy of Sciences of Armenia (Armenia) Viacheslav Voronin, Don State Technical University

(Russian Federation)

Yue Wu, Tufts University (United States)

Yicong Zhou, University of Macau (Macao, China)

\section{Session Chairs}

1 Multimedia Algorithms and Systems

Sabah Jassim, The University of Buckingham (United Kingdom)

2 Image Processing and Enhancement

Sos S. Agaian, The University of Texas at San Antonio (United States)

3 Multimedia Security and Sensing

Stephen P. DelMarco, BAE Systems (United States) 